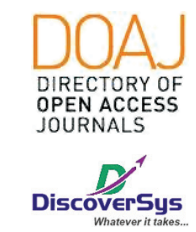

Published by DiscoverSys

\title{
Hubungan prematuritas dengan kejadian sepsis neonatorum yang dirawat di ruang perinatologi dan Neonatal Intensive Care Unit (NICU) RSUD Wangaya kota Denpasar
}

\author{
I Gusti Amanda Jaya, ${ }^{*}$ I Wayan Bikin Suryawan, Putu Pramitha Rahayu
}

\section{ABSTRACT}

Background: Premature neonates have an immature immune system due to the lack of $\lg G$ antibodies. These antibodies do not cross the placenta from mother to baby at last trimester that can increase the risk of neonatal sepsis. This study aims to determine the relationship between prematurity and the incidence of neonatal sepsis at Perinatology Ward and NICU Wangaya General Hospitals, Denpasar.

Methods: This research used analytical observation with cross sectional study design from January-April 2018. The samples involved are 50 neonates, admitted at Perinatology Ward and NICU Wangaya
Hospital and fulfilled the inclusion and exclusion criteria. Samples were obtained by using consecutive sampling method and using secondary data from the medical record

Result: 23 samples (46\%) premature and 27 samples (54\%) were not premature, out of 50 samples as many as 20 samples with neonatal sepsis. From the results of hypothesis testing using the chi-square test, the $p$-value is 0.005 , and the prevalence risk was 2.73 .

Conclusion: Prematurity is significantly related with the incident of neonatal sepsis at Perinatology Ward and NICU Wangaya Hospital, Denpasar City.

Keywords: neonatal, prematurity, neonatal sepsis

Cite This Article: Jaya, I.G.A., Suryawan, I.W.B., Rahayu, P.P. 2019. Hubungan prematuritas dengan kejadian sepsis neonatorum yang dirawat di ruang perinatologi dan Neonatal Intensive Care Unit (NICU) RSUD Wangaya kota Denpasar. Intisari Sains Medis 10(1): 18-22. D0I: 10.1556/ism. v10i1.319

\section{ABSTRAK}

Latar Belakang: Neonatus prematur mempunyai sistem kekebalan tubuh yang belum matang karena kekurangan antibodi IgG. Antibodi ini tidak melewati plasenta dari ibu ke darah janin saat akhir kehamilan sehingga meningkatkan risiko terjadinya infeksi setelah lahir hingga akhirnya menjadi sepsis neonatorum. Penelitian ini bertujuan untuk mencari tahu hubungan antara prematuritas dengan kejadian sepsis neonatorum yang dirawat di ruang Perinatologi dan NICU RSUD Wangaya Kota Denpasar.

Metode: Penelitian observasional analitik dengan rancangan penelitian cross sectional yang dilaksanakan sejak bulan Januari-April 2018. Sampel penelitian adalah 50 neonatus yang memenuhi kriteria inklusi dan eksklusi yang dirawat di ruang Perinatologi dan NICU RSUD Wangaya Kota Denpasar. Sampel diperoleh melalui metode consecutive sampling dan pengumpulan data menggunakan data sekunder dari rekam medis.

Hasil: 23 sampel (46\%) prematur dan 27 sampel (54\%) tidak prematur, dari 50 sampel sebanyak 20 sampel yang mengalami sepsis neonatorum. Dari hasil uji hipotesis dengan menggunakan uji chi square didapatkan nilai p sebesar 0,005, dan risiko prevalens sebesar 2,73.

Simpulan: Prematuritas secara signifikan berhubungan dengan kejadian sepsis neonatorum yang dirawat di ruang Perinatologi dan NICU RSUD Wangaya Kota Denpasar.
Bagian/SMF IImu Kesehatan Anak RSUD Wangaya, Bali-Indonesia

*Corresponding:

I Gusti Amanda Jaya, Bagian/

SMF IImu Kesehatan Anak RSUD

Wangaya, Bali-Indonesia

jaya.amanda@yahoo.co.id

Received: 2018-10-02

Accepted: 2018-10-07

Published: 2019-04-01
Kata kunci: neonatus, prematuritas, sepsis neonatorum

Cite Pasal Ini: Jaya, I.G.A., Suryawan, I.W.B., Rahayu, P.P. 2019. Hubungan prematuritas dengan kejadian sepsis neonatorum yang dirawat di ruang perinatologi dan Neonatal Intensive Care Unit (NICU) RSUD Wangaya kota Denpasar. Intisari Sains Medis 10(1): 18-22. D0I: 10.1556/ism. v10i1.319

\section{PENDAHULUAN}

Berdasarkan data dari World Health Organization (WHO) pada tahun 2011 melaporkan angka kematian neonatus sebesar 24 per 1000 kelahiran hidup dan $80 \%$ kematian neonatus terjadi di negara berkembang. Penyebab kematian neonatus antara lain akibat infeksi, asfiksia, komplikasi berat badan lahir rendah (BBLR) dan kelainan kongenital. Penyakit infeksi salah satunya adalah sepsis neonatorum. ${ }^{1}$ 
Sepsis neonatorum adalah suatu sindroma klinis oleh bakteri, virus, dan jamur yang ditandai dengan gejala dan tanda sistemik serta menunjukkan kultur darah positif yang terjadi pada bulan pertama kehidupan. ${ }^{2}$ Angka kejadian sepsis neonatorum di negara berkembang meningkat yaitu 1,8-18 per 1000 kelahiran hidup, dan di negara maju sebanyak 1-5 per 1000 kelahiran hidup. ${ }^{3}$ Sedangkan kasus kematian sepsis neonatorum di Indonesia sebesar 50-60\%. ${ }^{4} \mathrm{Di}$ rumah sakit umum pusat Sanglah, dilaporkan dari Januari 2003 sampai dengan Desember 2004 insiden sepsis neonatus $5,3 \%$ dengan tingkat kematian $56 \%{ }^{5}$

Sepsis neonatorum dibagi menjadi 2 kategori berdasarkan waktu terjadinya yaitu sepsis neonatorum awitan dini (SNAD) dan sepsis neonatorum awitan lambat (SNAL). ${ }^{6}$ Faktor risiko yang berhubungan terhadap kejadian sepsis neonatorum meliputi beberapa faktor yaitu dari faktor ibu, bayi, dan nosokomial. Faktor ibu antara lain ketuban pecah dini, demam selama kehamilan, dan ketuban hijau. Faktor bayi yang memengaruhi sepsis neonatorum antara lain BBLR, APGAR score, dan usia gestasi. Prematuritas memiliki risiko kesakitan dan kematian yang tinggi pada masa gestasi untuk terjadinya sepsis neonatorum. ${ }^{2}$

Prematuritas adalah bayi yang lahir pada saat usia kehamilan kurang dari 37 minggu. Setiap tahun dicatat sebanyak 15 juta bayi lahir prematur di dunia dan jumlahnya selalu meningkat di hampir semua negara. Bayi prematur mempunyai sistem kekebalan tubuh yang belum matang karena kekurangan antibodi IgG. Antibodi tersebut tidak melewati plasenta dari ibu ke darah janin saat pada akhir kehamilan sehingga meningkatkan risiko terjadinya infeksi setelah lahir hingga akhirnya menjadi sepsis neonatorum. ${ }^{2}$

\section{METODE}

Penelitian ini merupakan penelitian observasional analitik dengan rancangan penelitian cross sectional yang bertujuan untuk mencari hubungan antara prematuritas dengan kejadian sepsis neonatorum yang dirawat di ruang Perinatologi dan NICU RSUD Wangaya Kota Denpasar. Penelitian ini dilakukan di Ruang Perinatologi dan NICU RSUD Wangaya kota Denpasar periode Januari-April 2018. Besar sampel mínimal pada penelitian ini adalah 50 sampel yang dipilih menggunakan teknik consecutive sampling.

Sampel dipilih dengan mempertimbangkan kriteria inklusi berupa neonatus (0-28 hari) yang dirawat di ruang Perinatologi dan NICU RSUD Wangaya Kota Denpasar, dan data rekam medis pasien lengkap. Sedangkan kriteria ekslusi antara lain neonatus dengan kelainan kongenital, riwayat penyakit imunologi pada ibu, ibu mengalami ketuban pecah dini $>18$ jam, korioamnionitis, demam saat intrapartum $>38^{\circ} \mathrm{C}$, mengalami infeksi saluran kemih atau tersangka infeksi saluran kemih, mengalami ketuban mekoneal dan berbau, kehamilan $>1$, ada riwayat pemberian antibiotika. Penilaian prematuritas dengan pemeriksaan fisik lalu dicocokan dengan kriteria Finstrom.

Sumber data dalam penelitian ini adalah berupa data sekunder yang berasal dari rekam medis pasien. Pada penelitian ini dilakukan analisis univariat untuk mendeskripsikan karakteristik responden, lalu dilanjutkan ke analisis bivariat untuk menghubungkan antara variabel bebas dengan variabel terikat dengan menggunakan uji Chi Square dan diolah dengan Statistical Product and Service Solution (SPSS) 23 for Windows. Tingkat kemaknaan yang digunakan yaitu $10 \%(\alpha=0,1)$.

\section{HASIL}

Didapatkan pasien yang menderita sepsis neonatorum sebanyak 20 sampel (40\%), sedangkan yang tidak menderita sepsis neonatorum sebanyak 30 sampel (60\%). Berdasarkan jenis kelamin yang menderita sepsis neonatorum sebanyak 9 sampel (18\%) perempuan, 11 sampel (22\%) lakilaki. Berdasarkan usia kehamilan paling banyak yang menderita sepsis neonatorum pada kelompok prematur yaitu sebanyak 14 sampel (28\%),6 sampel $(12 \%)$ tidak prematur. Menurut berat badan lahir pada kelompok yang menderita sepsis neonatorum paling banyak pada kelompok BBLR yaitu sebanyak 16 sampel (32\%), 4 sampel (8\%) tidak BBLR. Rerata usia ibu yang menderita sepsis neonatorum adalah $28.75 \pm 5.71$ Menurut cara persalinan pada kelompok sepsis neonatorum paling banyak pada kelompok dengan tindakan yaitu sebanyak 11 sampel (22\%), 9 sampel (18\%) dengan persalinan normal. Berdasarkan luaran pada kelompok sepsis neonatorum paling banyak pada kelompok hidup dengan 18 sampel (36\%), 2 sampel (4\%) meninggal. Sampel yang menderita sepsis neonatorum paling banyak pada APGAR score rendah (0-3) yaitu sebanyak 8 sampel (16\%), lalu diikuti dengan APGAR score sedang dan normal (Tabel 1)

Sampel yang prematur adalah 23 sampel (46\%) dan yang tidak prematur 27 sampel (54\%). 14 sampel dari 23 sampel yang prematur mengalami sepsis neonatorum (28\%). Tabel 2 memperlihatkan hasil uji hipotesis dengan menggunakan uji chi square, dimana didapatkan nilai $\mathrm{p}=0,005$ dan risiko prevalensi didapatkan sebesar 2,73 dengan nterval kepercayaan 95\% sebesar 1.25 - 5.96, dimana tidak mencakup angka 1, yang berarti dalam populasi hal tersebut di atas benar terjadi. 
Tabel 1 Karakteristik Sampel Penelitian

\begin{tabular}{|c|c|c|c|}
\hline Variabel & $\begin{array}{c}\text { Sepsis Neonatorum } \\
20(40 \%)\end{array}$ & $\begin{array}{c}\text { Tidak Sepsis Neonatorum } \\
30(60 \%)\end{array}$ & Jumlah Total \\
\hline \multicolumn{4}{|l|}{ Jenis kelamin } \\
\hline Perempuan (\%) & $9(18 \%)$ & $10(20 \%)$ & $19(38 \%)$ \\
\hline Laki-laki (\%) & $11(22 \%)$ & $20(40 \%)$ & $31(62 \%)$ \\
\hline \multicolumn{4}{|l|}{ Usia kehamilan } \\
\hline Prematur (\%) & $14(28 \%)$ & $9(18 \%)$ & $23(46 \%)$ \\
\hline Tidak prematur (\%) & $6(12 \%)$ & $21(42 \%)$ & $27(54 \%)$ \\
\hline \multicolumn{4}{|l|}{ Berat badan lahir } \\
\hline BBLR (\%) & $16(32 \%)$ & $9(18 \%)$ & $25(50 \%)$ \\
\hline Tidak BBLR (\%) & $4(8 \%)$ & $21(42 \%)$ & $25(50 \%)$ \\
\hline Usia ibu $($ mean $\pm \mathrm{SD})$ & $28.75 \pm 5.71$ & $28.90 \pm 5.75$ & $28.84 \pm 5.67$ \\
\hline \multicolumn{4}{|l|}{ Cara persalinan } \\
\hline Normal (\%) & $9(18 \%)$ & $11(22 \%)$ & $20(40 \%)$ \\
\hline Tindakan (\%) & $11(22 \%)$ & $19(38 \%)$ & $30(60 \%)$ \\
\hline \multicolumn{4}{|l|}{ Luaran } \\
\hline Hidup (\%) & $18(36 \%)$ & $20(40 \%)$ & $38(76 \%)$ \\
\hline Meninggal (\%) & $2(4 \%)$ & $10(20 \%)$ & $12(24 \%)$ \\
\hline \multicolumn{4}{|l|}{ APGAR score } \\
\hline Rendah (\%) & $8(16 \%)$ & $4(8 \%)$ & $12(24 \%)$ \\
\hline Sedang (\%) & $7(14 \%)$ & $10(20 \%)$ & $17(34 \%)$ \\
\hline Normal (\%) & $5(10 \%)$ & $16(32 \%)$ & $21(42 \%)$ \\
\hline
\end{tabular}

Tabel 2 Hubungan Prematuritas dengan Sepsis Neonatorum

\begin{tabular}{lccccc}
\hline Variabel & $\begin{array}{c}\text { Sepsis } \\
\text { Neonatorum } \\
\mathbf{2 0}(\mathbf{4 0 \% )}\end{array}$ & $\begin{array}{c}\text { Tidak Sepsis } \\
\text { Neonatorum } \\
\mathbf{3 0}(\mathbf{6 0 \% )}\end{array}$ & Total & RP (IK 95\%) & $\boldsymbol{P}$-value \\
\hline Prematur & $14(28 \%)$ & $9(18 \%)$ & $23(46 \%)$ & $2.73(1.25-5.96)$ & 0.005 \\
Tidak Prematur & $6(12 \%)$ & $21(42 \%)$ & $27(54 \%)$ & & \\
\hline
\end{tabular}

Keterangan: RP = Risiko Prevalensi; $\mathrm{IK}=$ Interval Kepercayaan

\section{DISKUSI}

Jenis kelamin dibagi menjadi 2 kelompok, yaitu laki-laki dan perempuan. Proporsi laki-laki adalah $62 \%$ dan perempuan sebanyak $38 \%$. Sebagian besar jenis kelamin pada kelompok sepsis neonatorum adalah laki-laki 11 neonatus (22\%), sedangkan pada kelompok perempuan sebanyak 9 neonatus (18\%). Menurut penelitian yang dilakukan Sheikh AM et al (2010) di Lahore menyatakan bahwa sepsis neonatorum lebih sering terjadi pada neonatus dengan jenis kelamin laki-laki. ${ }^{7}$ Hal ini dapat disebabkan oleh karena faktor yang terkait seks dalam kerentanan host terhadap infeksi. Kromosom X memiliki gen yang mempengaruhi fungsi dari kelenjar timus dan sintesis immunoglobulin. Sedangkan laki-laki hanya memiliki satu kromosom X, sedangkan perempuan memiliki kromosom X ganda sehingga laki-laki lebih rentan terhadap infeksi dibanding perempuan. ${ }^{8,9}$
Karakteristik berat badan lahir pada penelitian ini memiliki proporsi yang sama antara BBLR (50\%) dan tidak BBLR (50\%). Pada kelompok sepsis neonatorum paling banyak neonatus dengan BBLR yaitu 16 neonatus (32\%). Hal ini sejalan dengan studi yang dilakukan oleh Junara (2012) dimana dikatakan BBLR memiliki resiko 2,6 kali lebih besar mengalami sepsis neonatorum. ${ }^{10} \mathrm{Hal}$ itu karena pematangan organ tubuhnya yang belum sempurna yang bisa menyebabkan bayi lebih mudah terkena infeksi. ${ }^{11}$ Kemungkinan lainnya adalah karena BBLR sering mengalami kesulitan atau kurang mampu menghisap dan mencerna ASI yang berakibat terjadinya penurunan daya tahan tubuh dan memudahkan terjadinya infeksi. ${ }^{12}$

Jenis persalinan pada sampel penelitian ini didominasi oleh sampel dengan riwayat persalinan 
dengan tindakan yaitu sebanyak $60 \%$, sedangkan persalinan normal sebanyak $40 \%$ dari keseluruhan. Kejadian sepsis neonatorum lebih banyak pada sampel dengan jenis persalinan dengan tindakan yaitu sejumlah 11 sampel (22\%). Hasil penelitian sejalan dengan penelitian yang dilakukan oleh Simbolon (2008) yang menyebutkan bahwa kejadian sepsis neonatonun lebih banyak pada bayi dengan riwayat persalinan dengan tindakan, bayi yang lahir dengan tindakan dapat berisiko 2,142 kali mengalami sepsis neonatorum dibandingkan dengan bayi yang lahir secara normal Hal ini mungkin terjadi karena kontaminasi kuman yang terjadi setelah lahir, seperti alat-alat yang digunakan saat dilakukan persalinan yang terkontaminasi. ${ }^{13}$

Pada kelompok sepsis neonatorum rerata usia ibu dari sampel adalah berusia $28.75 \pm 5.71$. Itu sesuai dengan penelitian Lestari (2012) dan Ningsih (2016) yang mengatakan presentase pasien dengan sepsis neonatorum berdasarkan karakteristik usia ibu paling tinggi pada usia 20-30 tahun yang dimana itu adalah usia produktif. ${ }^{14,15}$ Berdasarkan luaran untuk kasus sepsis neonatorum pada penelitian ini didapatkan sebagian besar yaitu sebanyak 18 sampel (36\%) hidup dan hanya sebagian kecil yaitu sebanyak 2 sampel (4\%) meninggal. Sedangkan pada penelitian yang dilakukan Junara (2012) dikatakan angka kematian yang diakibatkan sepsis neonatorum mencapai $30,4 \%$ yang dimana itu jauh lebih tinggi daripada penelitian ini. ${ }^{10}$

Bayi yang sepsis neonatorum paling banyak pada APGAR score rendah (0-3) yaitu sebanyak 8 sampel (16\%) diikuti oleh APGAR score sedang (4-6) sebanyak 7 sampel (14\%) dan paling sedikit pada yang memiliki APGAR score normal (7-10) yaitu sebanyak 5 sampel (10\%). Hal itu sejalan dengan penelitian yang dilakukan Leal (2012) yang mengatakan bahwa bayi yang lahir dengan APGAR score $\leq 5$ memiliki peluang 1,4 kali lebih besar untuk mengalami sepsis neonatorum dibandingkan dengan bayi yang lahir dengan APGAR score $>5 .{ }^{16}$

Penelitian ini dilakukan untuk mencari hubungan antara prematuritas dengan kejadian sepsis neonatorum. Didapatkan 23 sampel (46\%) prematur dan 27 sampel (54\%) tidak prematur, dari 50 sampel sebanyak 20 sampel yang mengalami sepsis neonatorum. Dari hasil penelitian ini didapatkan nilai $\mathrm{p}$ sebesar 0,005 . Karena nilai $\mathrm{p}<0,05$, maka dapat disimpulkan bahwa terdapat hubungan yang signifikan antara prematuritas dengan sepsis neonatorum. Dari hasil perhitungan didapatkan risiko prevalensi yaitu 2,73. Hal ini berarti prematuritas benar-benar berpengaruh terhadap terjadinya sepsis neonatorum sebesar 2,73 kali. Interval kepercayaan 95\% sebesar 1,25-5,96, dimana tidak mencakup angka 1, yang berarti dalam populasi hal tersebut di atas benar terjadi. Hasil penelitian ini sejalan dengan penelitian yang dilakukan oleh Dini FN (2016) sebelumnya yang menunjukkan bahwa terdapat hubungan antara masa gestasi dan kejadian sepsis neonatorum di RSUD Ulin Banjarmasin $(\mathrm{p}=0,000)$ dengan odds ratio (OR) 6,256. ${ }^{17}$ Begitu juga penelitian yang dilakukan Sari E dkk (2016) yang menyebutkan ada hubungan antara tingkat maturitas dengan kejadian sepsis neonatorum terbukti secara statistik, dimana didapatkan keseluruhan yang menderita sepsis neonatorum sebanyak 43 sampel, sedangkan yang yang prematur dan menderita sepsis neonatorum sebanyak 34 sampel dengan $\mathrm{p}$ sebesar 0,017 dengan odds ratio (OR) $3,257 .^{18}$

Kaitan antara prematuritas dengan sepsis neonatorum disebabkan oleh karena kekebalan sistem humoral dan selular yang kurang. pembentukan sistem imun pada bayi prematur kurang sempurna dan mengakibatkan bayi prematur akan lebih mudah mengalami sepsis. Antibodi ibu transplasenta yang awalnya menghasilkan kekebalan humoral (immunoglobulin), cenderung diterima oleh bayi premature namun tidak sebanyak pada bayi cukup bulan. Bayi prematur memiliki immunoglobulin yang sangat rendah, karena Ig secara pasif ditransfer melalui plasenta selama trimester terakhir kehamilan. ${ }^{19,20,21}$ Selain itu, bayi prematur memerlukan intervensi, rawat inap yang lebih panjang sehingga dapat meningkatkan risiko infeksi nosokomial yang dapat menyebabkan sepsis neonatorum. $^{21}$

\section{KETERBATASAN}

Kelemahan pada penelitian ini antara lain, data dalam penelitian ini masih menggunakan data sekunder dan pada penelitian ini variabel independen yang diteliti hanya terbatas pada prematuritas, sehingga beberapa faktor risiko lain dalam pustaka yang kemungkinan berhubungan dengan variabel dependen (sepsis neonatorum) tidak dianalisis. Faktor risiko yang menyebabkan terjadinya sepsis neonatorum sangatlah bervariasi, oleh karena itu perlu dilakukan penelitian lebih lanjut mengenai faktor risiko lainnya yang berhubungan dengan sepsis neonatorum dengan cakupan populasi terjangkau yang lebih luas. Selain itu subyek dalam penelitian kurang variatif karena hanya mengambil dari satu rumah sakit sehingga tidak bisa digeneralisasikan serta waktu dalam pengumpulan sampel yang cukup singkat. 


\section{SIMPULAN}

Terdapat hubungan yang signifikan antara prematuritas dengan kejadian sepsis neonatorum di ruang Perinatologi dan NICU RSUD Wangaya Kota Denpasar.

Diharapkan dapat dilakukan penelitian lebih lanjut mengenai faktor-faktor yang mempengaruhi kejadian sepsis neonatorum selain prematuritas sehingga diketahui faktor yang paling berpengaruh dan diharapkan dapat dilakukan penelitian menggunakan metode yang lebih kuat dengan jumlah sampel yang lebih besar sehingga diperoleh hasil yang lebih bisa mewakili dan dapat direpresentasikan dengan lebih baik pada populasi.

\section{DAFTAR PUSTAKA}

1. WHO. WHO statistics 2011. http://www.doh.gov.za/docs/ stats/2011/who.pdf. (diakses pada 23 April 2018)

2. Kosim MS, Yunanto A, Dewi R, Sarosa GI, Usman A. Buku Ajar Neonatologi Edisi Pertama. Jakarta: BadanPenerbit IDAI. 2014.

3. Nasution DA. Faktor risiko dan kesamaan jenis kuman jalan lahir ibu dengan kultur darah pada sepsis neonatal awitan dini [tesis]. Semarang: Universitas Diponegoro. 2008.

4. Djaja S. Penyakit penyebab kematian bayi baru lahir dan sistem pelayanan kesehatan yang berkaitan di Indonesia. 2003. http://www/litbang.depkes.go.id. (diakses pada 20 April 2018)

5. Suarca IK, Kardana M, Iswari IS, penyunting. Blood culture and sensitivity test pattern of early versus late onset sepsis in neonatal ward sanglah hospital denpasar. Prosiding the 13th National Congress of Child Health KONIKA XIII: Bandung, Indonesia. 2005.

6. Departemen kesehatan RI: Penyebab utama sepsis neonatorum dan angka kematian ibu dan bayi. Jakarta. 2007.

7. Sheikh AM, Javed T, Afzal MF, Sheikh CA. Course and complications of early onset neonatal sepsis: a descriptive study. Annals 2010. 16: 307-10.

8. Mendoza UA. Sepsis Neonatorum at manila central university filemon d. Tanchoco Med Foundation (MCUFDTMF). Calacoon City. Manila. 2000.
9. Wilar R, Daud D, As'ad S, Febriani DB, Mina. A comparison of neutrophil gelatinase-associated lipocalin and immature to total neutrophil ratio for diagnosing early-onset neonatal sepsis. Paediatrica Indonesiana, 2016. 56(2): pp.107-10.

10. Junara, P. Insiden dan faktor-faktor yang berhubungan dengan sepsis neonatorum neonatus di RSUP sanglah denpasar. Sari Pediatri. 2012.

11. Mark HB, Robert B. From the merck manual of medical information home edition. New Jork. 1997.

12. Fikawati, S. Kajian implementasi dan kebijakan air susu ibu eksekutif dan inisiasi menyusui dini di indonesia. 2010.

13. Simbolon D. Faktor risiko sepsis pada bayi baru lahir di RSUD curup kabupaten rejang lebong. Politeknik Kesehatan Bengkulu. 2008.

14. Lestari D, Sarumpaet SM. Karakteristik penderita sepsis neonatorum rawat inap di RSUD Dr. Pirngadi Medan tahun 2010-2011. Gizi, Kesehatan Reproduksi dan Epidemiologi. 2013;1(2).

15. Ningsih N. Hubungan BBLR, KPD, dan persalinan prematur dengan kejadian sepsis neonatus di badan layanan umum daerah rumah sakit benyamin guluh kabupaten kolaka tahun 2016. Kendari. Fakultas Kesehatan Masyarakat Universitas Halu Oleo. 2016.

16. Leal YA, Álvarez-Nemegyei J., Velázquez JR., et al. Risk factors and prognosis for neonatal sepsis in southeastern mexico: analysis of a four-year historic cohort follow-up. BMC Pregnancy Childbirth. 2012;12: 48.

17. Dini FN, Andayani P, Rosida L. Hubungan antara masa gestasi dan kejadian sepsis neonatorum di RSUD ulin banjarmasin periode juni 2014-juni 2015. Berkala Kedokteran; 2016. Vol.12: 175-185

18. Sari E, Mardalena. Faktor-faktor yang berhubungan dengan kejadian sepsis pada neonatorum di rumah sakit moehammad hoesin palembang. Rakernas Aipkema. 2016.

19. Bentlin MR, Rugolo LMSS. Late onset sepsis: epidemiology, evaluation, and outcome. Neo Reviews. 2010; 11:426-35.

20. Edmond K, Zaidi A. New approaches to preventing, diagnosing, and treating neonatal sepsis. PLoS Medicine. 2010:7:1-7.

21. Trotman H, Bell Y, Thame M, Nicholson AM, Barton M. Predictor of poor outcome in neonates with bacterial sepsis admitted to the University Hospital of the West Indies. West Indian Med J 2006; 55:80-4.

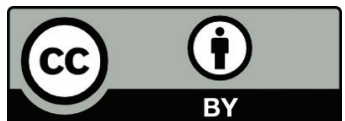

This work is licensed under a Creative Commons Attribution 